from adenoids than those who sleep with closed windows, it may at least be admitted that they, together with Pro. fessor Thomson's observations, show that serious and immediate attention should be given to the subject. The hope was expressed that Professor Thomson's paper would be "carefully considered and its lessons acted upon." To do this surely we should be justified in advocating that windows ought not to be kept open on cold and damp nights, in the sleeping rooms of children at least. I believe that from 80 to 90 per cent. of " adenoids" could be almost immediately prevented by the promulgation of this doctrine, for there is no donbt that mothers would willingly adopt it at once if they had the sanction and authority of the medical profession. I am, Sir, yours faithfully,

Wimpole-street, W., April 13th, 1903. J. Sim WALLACE.

\section{SMALL-POX AND DISINFECTION ON BOARD SHIP.}

To the Editor of THE LANCET.

SIR,-Your correspondent "J. F. B.," whose letter on the above subject appeared in your issue of March 21st, asks for reference to articles or records of experiments indicating the value of formalin as a disinfectant in such circumstances. Klein, Sommerville, and others have done experimental work on the germicidal efficiency of formalin. In the British Medical Journal of July 2nd, 1904, experiments are recorded by Sommerville in which formalin is put in competition with carbolic acid in the destruction of $B$. typhosus and the results show that the coefficient of formalin is 0.4 , taking that of carbolic acid as 1.0. In the Sanitary Record of Nov. 29th, 1906, Sommerville and myself, working with a modification of the above method, in which various organic matters (serum, gelatin, mucin, \&c.) are introduced, record a coefficient for formalin ranging from 0.2 to 03 ; and in the same journal of May 9th, 1907, working with larger quantities of organic matter, we find the same coefficient for this body-viz., $0 \cdot 2$ to 0.3 .

It is clear that fumigation with any body of such low germicidal strength must be a most unsatisfactory method of disinfecting ships. The same remark applies to famigation with $\mathrm{SO}_{2}$. Nearly 30 years ago the whole question of the disinfectant value of this gas $\left(\mathrm{SO}_{2}\right)$ was investigated in Germany by Koch, Wolfhügel, Hüppe, and Proskauer, and the report of these experts stated that sulphur dioxide, with or without water, dry or damp, was entirely useless for the disinfection of spores and quite unreliable for the disinfection of sporeless organisms in the presence of any superficial protection. It was further demonstrated that in practice the unequal diffusion of the gas and its loss through various causes rendered the disinfectant value much less than in the laboratory experiments, and these scientists strongly recommended that disinfection by sulphur dioxide should be entirely abandoned. Dujardin-Beaumetz, Cassedebat, Sternberg, and others have described the use of this gas as wholly unreliable, a farce, and simply ridiculous. The vapours of formalin and sulphur dioxide, lacking, as they are, so largely in germicidal efficiency, are now superseded by the application of liquid disinfectants of high coefficiency. A mop or spray and warm watery dilution of one of these form the most effective implements for the disinfection of the various apartments, berths, \&c., aboard ship.

$$
\text { I am, Sir, yours faithfully, }
$$

$$
\text { J. T. AINSLIE WALKER, F.C.S. }
$$

Kew Gardens, April 11th, 1908

Sussex Milk-vendors Fined,-The sequel to samples of milk from Sussex being taken at Thornton Heath station, London, at the latter end of February, came before the Croydon magistrates on April 7th, when the Etchingham Milk and Cream Company, Limited, and John Everatt, of Cooksbridge, were fined, the former company $£ 3$ and costs and the latter defendant $£ 2$ and costs, for selling to retail dealers milk deficient of fat. In the case of the defendant company it was stated that the railway company (the South-Eastern and Chatham Railway) had complained of the condition of the churns; and in the other case the defendant said that he did not seal his churns because the railway company (the London, Brighton, and South Coast Railway in this case) reserved the right to inspect them. 8 per cent. of added water was found in the sample of milk from Cooksbridge and in the other case the milk was deficient of 40 per cent. of fat.

\section{SANITATION AND THE SLAUGHTER- HOUSE AT STUTTGART.}

(From our Spectal Sanitary Commissioner.)

Wine for THE PoOR.-Medical Inspection of School Children.-SUCCessful Measures against Venereal Disease - The WÚtemberg Troops the Least Contaminated. - Sale and Re-purchase, at Great Loss, of the Abattolr.-Inspection and Control of MeAT.-The Cost.

STUTTGART among its many attractions affords points of special interest to the student of sanitation. By reason of its importance and population it holds the twelfth place among the 36 largest towns of the German Empire. Since 1877 its medical officer of health has not been allowed private practice but must devote his whole time to the public service. In 1883 a second medical officer was appointed whose principal task is to attend to prostitutes and to prevent the spread of venereal disease. A third medical officer was nominated to superintend the insane and the poor-house. Finally, in 1903, a bacteriological instirute was established. The chief medical officer of health has to watch over the work of the other officers. He has also to instruct and to advise the town councillors and the police in all matters relating to insanitary dwellings, drainage, factories, milk, food, and drug supplies, the care of the insane, \&c. The city, which used to consist of only seven, has now 14 wards. There are several "doctors of the poor" who receive from the municipality $£ 25$ a year and have to give full medical attendance to the indigent living in their wards. They also have to advise in regard to the care of orphans and decide the amount and nature of the relief that should be given. Thus, in 1906 the food given to sick persons amounted to 13500 portions and 4551 litres of wine. From this it will be seen how in Suabia wine is considered an important article of diet and a help in restoring the strength of the sick ; indeed, this is another illustration of the fact that in wine-growing countries the fear of intemperance is not entertained.

In regard to the medical inspection of school children the question has not been neglected, but at the time of my visit the authorities were waiting to discover the right way of organising this service. There was a risk of a conflict of authorities. Dr. Krauss, the first medical officer of the city, was sent all over Germany to study what had been done elsewhere, but the results of his investigations were not at all satisfactory. In the meanwhile the chief medical officer of health receives twice a year in his own surgery all the schoolchildren. The first examination is very thorough and conducted for the purpose of discovering any constitutional defect. If this is found, the medical officer decides whether the child should be sent to the salt baths, to a school colony in the country or on the hills, or what other mode of treatment is necessary. Whatever has to be done, it is done forthwith. The cost is at once defrayed by the city but the public authorities sometimes endeavour to recover the whole or part of the outlay from the parents. Also the cost is at times in part met by the insurance to which the parents contribute. In any case the treatment of the child is taken in hand at once and this is not delayed by questions as to who should pay the cost.

It is, however, in coping with venereal disease that the authorities at Stuttgart have been most successful. The system adopted differs considerably from that which prevails in most other towns. There are in Stuttgart, in spite of its population of 260,000 persons, only 16 women regularly inscribed as prostitutes. These women voluntary inscribe themselves so as not to be troubled by the police and present themselves for periodical examination. The real measure of protection adopted is that of establishing a very careful watch in the streets. Whenever there is reason to believe that a woman is practising prostitution she is arrested and examined. In 1906, the last year for which I was able to obtain figures, 1172 women were thus examined. Of these, two had soft ulcers; $118 \mathrm{had}$ gonorrhœa, and of these $15 \mathrm{had}$ syphilis as well; and there were 45 cases of syphilis. Thus there were 180 cases of venereal disease out of 1172 women examined. This represents a considerable decrease as compared to the figures given some years ago. The percentage of disease is now reckoned as 0.17 per cent. soft ulcers, $11 \cdot 3$ per cent. gonorrhca, $5^{\cdot 1}$ per cent. syphilis; total, $16 \cdot 6$ per cent. 